ISSN 1978-2071 (Print); ISSN 2580-5967 (Online)

Jurnal Ilmiah Kedokteran Wijaya Kusuma 9(2) : 209-217, September 2020

\title{
Pengaruh Ekstrak Undur-undur (Myrmeleon sp) terhadap Glukosa Darah dan Hematokrit pada Tikus Diabetes
}

\author{
Djap Hadi Susanto ${ }^{*}$, Ronald Winardi Kartika², Pamela Hendra Heng ${ }^{3}$, Adit Widodo Santoso ${ }^{4}$, \\ Maria VB Lopulalan ${ }^{4}$, Angelina Wijaya ${ }^{4}$ \\ Departemen Ilmu Kesehatan Masyarakat FK UKRIDA ${ }^{1}$ \\ Departemen Bedah FK UKRIDA ${ }^{2}$ \\ Departemen Psikologi Untar ${ }^{3}$ \\ Departemen Biokimia K UKRIDA ${ }^{4}$ \\ *e-mail: djaphs@ukrida.ac.id
}

\begin{abstract}
Abstrak
Diabetes Mellitus (DM) merupakan salah satu masalah kesehatan utama di dunia maupun Indonesia. Prevalensinya semakin meningkat dan trend kejadiannya semakin bergeser ke usia muda. Pengobatan DM membutuhkan biaya mahal dan dilakukan seumur hidup, merupakan masalah tersendiri. Sebagian besar masyarakat Indonesia masih menggunakan cara-cara pengobatan tradisional terutama obat ramuan dan herbal dari berbagai zat-zat hayati yang tersedia di alam bebas. Undur-undur (myrmeleon $s p$.) dipercaya mempunyai efek menurunkan glukosa darah penderita diabetes, dan juga mempunyai efek terhadap viskositas darah. Penelitian ini bertujuan mengetahui pengaruh ekstrak undur-undur terhadap penurunan glukosa darah dan hematokrit tikus diabetes. Desain penelitian adalah eksperimental acak pada tikus diabetes yang diinduksi dengan streptozocin, dosisnya $100 \mathrm{mg} / \mathrm{kg} / \mathrm{bb}$ tikus diberikan secara intraperitoneal. Lima puluh ekor tikus diabetes dibagi menjadi 2 kelompok dengan pemberian ekstrak undur-undur dosis 0,01 ml/ 200 gram BB tikus (100\%) dan 0,005 ml/ 200 gram BB tikus (50\%). Ekstrak undur-undur mempunyai efek menurunkan glukosa darah puasa dan hematokrit pada tikus diabetes. Terdapat perbedaan dosis pemberian ekstrak undur-undur antara $50 \%$ dan $100 \%$. Efek penurunan glukosa darah puasa dan hematokrit terjadi setelah hari kedua. Kesimpulan penelitian ini adalah ekstrak undur-undur dapat dipertimbangkan sebagai salah satu pengobatan tradisional penderita diabetes.
\end{abstract}

Kata Kunci: myrmeleon sp., diabetes mellitus, glukosa darah, hematokrit.

\section{Effect of ant lion (Myrmeleon sp.) on Blood Glucose and Hematocrit in Diabetic Rat}

\begin{abstract}
Diabetes Mellitus (DM) is one of the major health problems in the world and Indonesia. The prevalence is more increasing and also shows the trend of events is shifting to young age. Diabetes mellitus treatment requires high costs and also a lifetime. Most of the people of Indonesia still use traditional methods of treatment, especially herbs from various biological substances that are available in the environment. Undur-undur (myrmeleon sp.) is believed to have the effect of anti-hyperglycemia, and also antiviscosity. The aim of this study was to determine anti-hyperglycemia and anti-viscosity of myrmeleon sp. extract in diabetic rats. The design of study is randomized experiment. Diabetic rats were induced by
\end{abstract}


Pengaruh Ekstrak Undur-undur (Myrmeleon sp) terhadap Glukosa Darah dan Hematokrit pada Tikus... Djap Hadi Susanto, Ronald Winardi Kartika, Pamela Hendra Heng, Adit Widodo Santoso, Maria VB Lopulalan, Angelina Wijaya

streptozocin $100 \mathrm{mg} / \mathrm{kg}$ BW intraperitoneal. Fifty rats were divided into 2 groups administered by Myrmeleon sp. extract dose 0,01 ml/ 200 gram BW (100\%) and 0,005ml/ 200 gram BW (50\%). Myrmeleon sp. shows the effect of anti-hyperglycemic and anti-viscosity in diabetic rats. There was a difference between $50 \%$ and $100 \%$ doses. The effect of anti-hyperglycemia and anti-viscosity occurs after the second day. Conclusion: the extract of myrmeleon sp. could be considered as one of the traditional treatments of diabetic patients.

Keywords: Myrmeleon sp., diabetes mellitus, hyperglycemia, hematocrit

\section{PENDAHULUAN}

Diabetes melitus (DM) merupakan penyakit metabolik kronik dengan karakteristik hiperglikemia yang disebabkan oleh kerusakan atau menurunnya fungsi pankreas dalam menghasilkan insulin sehingga terjadi kelainan sekresi insulin, kerja insulin atau keduanya. Sebagai penyakit menahun, DM memerlukan perawatan medis berkelanjutan dan manajemen mandiri pasien yang berkelanjutan dan dukungan untuk mengurangi risiko kecacatan jangka panjang, mencegah komplikasi, dan kematian. Selain itu, membutuhkan biaya perawatan dan pengobatan yang mahal (Badan Litbangkes

Depkes RI, 2013; Huber et al, 2014).

Diabetes melitus (DM) merupakan suatu kelompok penyakit metabolik dengan karakteristik hiperglikemia yang terjadi karena kelainan sekresi insulin, kerja insulin atau keduanya. Banyak masyarakat yang menyebutnya sebagai penyakit glukosa atau kencing manis. Istilah-istilah tersebut tidak salah, DM boleh saja dikatakan sebagai penyakit glukosa karena memang konsentrasi glukosa atau glukosa dalam darah melebihi batas normal, dan bisa juga bila disebut sebagai kencing manis, karena didalam urin dengan keadaan normal tidak ada atau negatif kandungan glukosanya (Soegondo, 2008; PB Perkeni, 2015).

Angka kejadian kasus baru DM cenderung meningkat dari tahun ke tahun. Menurut International Diabetes Federation (IDF), sekitar 382 juta orang hidup dengan diabetes pada tahun 2013 dan jumlahnya diperkirakan mencapai 592 juta orang pada tahun 2035. (Whiting et al, 2011; Sudharsanan et al, 2015). Prevalensi DM di Indonesia mencapai 6,6\% pada laki-laki dan $7,1 \%$ pada perempuan, dan sebesar 6,9\% untuk total populasi (Badan Litbangkes Depkes RI, 2013). Berdasarkan data survey kesehatan dasar tahun 2013, prevalensi prediabetes $45 \%$ dan diabetes $12,8 \%$. (Djap et al, 2018). Hiperglikemia yang menginduksi stres oksidatif dilibatkan sebagai penyebab peningkatan viskositas darah utuh (whole blood viscosity = WBV). Sebagaimana diketahui, bahwa faktor-faktor yang meningkatkan WBV meliputi hematokrit, agregasi dan kelainan 
ISSN 1978-2071 (Print); ISSN 2580-5967 (Online)

Jurnal Ilmiah Kedokteran Wijaya Kusuma 9(2) : 209-217, September 2020

bentuk eritrosit, kadar protein plasma total, suhu tubuh, kecepatan dan diameter aliran darah. Dari beberapa penelitian ditemukan adanya peningkatan WBV dalam semua tahap hiperglikemia, termasuk tahap prediabetes. Hasil ini menegaskan adanya vaskulopati asimptomatik pada individu prediabetes yang memiliki risiko tinggi terkena komplikasi penyakit kardiovaskular (cardiovascular disease $=(V D)$. Penentuan viskositas darah dalam praktik klinis dapat menjadi alat pelengkap yang berguna dalam penilaian vaskulopati dan CVD pada prediabetes dan diabetes yang tidak terdiagnosis. Hasil lain yang ditemukan bahwa viskositas tinggi bervariasi pada berbagai tahap diabetes berhubungan dengan stres oksidatif eritrosit. Adanya korelasi yang kuat antara viskositas darah dengan kejadian diabetes mellitus (Tulloch-Reid et al, 2004). Penelitian pada penderita DM baik laki-laki dan perempuan, ditemukan fibrinogen secara signifikan lebih tinggi dari kontrol. (Wang et al, 2011; Irace et al, 2011).

Pengobatan DM memerlukan kepatuhan penderita yang tinggi, selain modifikasi pola asupan makanan, obat kimia juga harus diminum setiap hari dalam jangka waktu yang lama agar glukosa darah dapat terkontrol pada rentang yang normal. Banyak masyarakat Indonesia mencoba pengobatan alternatif dimana pengobatan altenatif antara lain dapat dilakukan dengan metode akupuntur, sedangkan untuk pengobatan tradisional dapat menggunakan tanaman maupun hewan yang berkhasiat obat atau ramuan tradisional lainnya yang lebih murah dengan risiko medis yang kecil. Penelitian sebelumnya menunjukkan bahwa ekstrak undur-undur memiliki aktivitas penghambatan tertinggi terhadap enzim $\alpha$ glukosidase (Mujahid, 2013).

Undur-undur termasuk kelas insektisida, subkelas neuroptera, famili myrmeleontidae. Larva undur-undur banyak ditemukan di tanah yang kering atau berpasir dengan ukuran antara $2 \mathrm{~cm}$ sampai $15 \mathrm{~cm}$. Larva undur-undur bersifat omnivora, biasanya memakan semut atau serangga lainnya. (Mujahid, 2013). Undur-undur mengandung zat aktif sulfonylurea yang mempunyai efek anti-hyperglikemik, antioksidan dan antibakteri (Narulita et al, 2019). Sulfonylurea yang terkandung di dalam undur-undur merupakan zat yang sama dengan sulfonylurea yang selama ini digunakan di dalam obat DM sintetis. Sulfonylurea dalam bentuk antidiabetik oral (zat yang berfungsi menurunkan glukosa darah) hanya cocok untuk mengobati DM tipe 2 karena cara kerjanya memperbaiki kerja pankreas dalam mensekresikan insulin, sedangkan pada penderita DM tipe 1, pankreasnya sudah tidak dapat memproduksi insulin secara permanen (Dewi, 2014). Undur-undur juga memiliki senyawa mirip metformin yang mampu menurunkan gula darah (Muadifah et al, 2007). 
Pengaruh Ekstrak Undur-undur (Myrmeleon sp) terhadap Glukosa Darah dan Hematokrit pada Tikus...

Djap Hadi Susanto, Ronald Winardi Kartika, Pamela Hendra Heng, Adit Widodo Santoso, Maria VB Lopulalan, Angelina Wijaya

Selain mempunyai efek anti-

hiperglikemia, undur-undur (Myrmeleon sp.)

juga memiliki efek terhadap kekentalan darah

(viskositas). Besarnya risiko viskositas darah

adalah hazard ratio $=1,68$ dan hematokrit

hazard ratio 1,63 . Seseorang yang mempunyai risiko ini, lebih dari 60\% akan berkembang menjadi diabetes (Tamariz et al, 2008). Efek antidiabetes pada undur-undur adalah dengan menghambat aktivitas enzim $\alpha$-glukosidase. Aktivitas inhibisi terbesar enzim $\alpha$-glukosidase ditemukan pada undur-undur muda. Perlu adanya pengembangan obat antihiperglikemia baru yang alami dalam pengobatan DM tipe II dengan harapan memiliki efektivitas yang maksimal dan efek samping yang sangat minimal (Sutanto, 2008; Mujahid, 2013).

Tujuan penelitian adalah diketahuinya pengaruh ekstrak undur-undur (Myrmeleon sp) terhadap glukosa darah dan hematokrit darah pada tikus diabetes. Manfaat penelitian diharapkan bahwa hasil penelitian dapat menjadi salah satu alternatif pengobatan diabetes melitus yang memanfaatkan potensi alamiah yang mudah didapat.

\section{BAHAN DAN METODE}

Desain penelitian menggunakan desain eksperimental. Hewan coba yang digunakan adalah tikus SD (Sprague Dawley) dengan berat rata-rata 130 gram. Jumlah sampel minimum 
ISSN 1978-2071 (Print); ISSN 2580-5967 (Online) Jurnal Ilmiah Kedokteran Wijaya Kusuma 9(2) : 209-217, September 2020 Tikus SD yang dapat diamati hanya sejumlah $21 \quad$ ekor.

Tabel 1. Distribusi berat badan tikus menurut dosis pemberian ekstrak undur-undur.

\begin{tabular}{lccccc}
\hline Berat badan & Mean & Median & SD & Min-max & $95 \% \mathrm{Cl}$ \\
\hline Dosis 100\% $(n=25)$ & 130.00 & 120 & 23,66 & $100-180$ & $345,98-509,93$ \\
Dosis 50\% $(n=25)$ & 133.00 & 121 & 22,89 & $101-181$ & $346,77-510,01$ \\
\hline
\end{tabular}

Catatan: berat badan tikus pada kondisi awal sebelum perlakuan

Pada uji normalitas variabel glukosa darah dan hematokrit pada hari 1 sampai ke 5 dengan menggunakan Shapiro-Wilk, didapatkan data terdistribusi secara normal, maka selanjutnya diuji kemaknaannya dengan repeated measures.

Tabel 2. Sebaran glukosa darah puasa dan hematokrit pada hari ke-1-5 menurut dosis undur-undur.

\begin{tabular}{|c|c|c|c|c|c|c|c|}
\hline \multicolumn{4}{|c|}{ Hematokrit } & \multicolumn{3}{|c|}{ Glukosa darah puasa } & \multirow[t]{2}{*}{$\mathrm{N}$} \\
\hline Hari & Dosis & Mean & Std. Deviation & Dosis & Mean & SD & \\
\hline & $100 \%$ & 49,48 & 1,286 & $100 \%$ & 375,43 & 196,203 & 14 \\
\hline \multirow[t]{3}{*}{ Hari1 } & $50 \%$ & 49,96 & 1,021 & $50 \%$ & 533,00 & 73,428 & 7 \\
\hline & Total & 49,64 & 1,199 & Total & 427,95 & 180,091 & 21 \\
\hline & $100 \%$ & 46,92 & 2,154 & $100 \%$ & 307,21 & 184,570 & 14 \\
\hline \multirow[t]{3}{*}{ Hari 2} & $50 \%$ & 48,86 & 0,958 & $50 \%$ & 496,71 & 86,295 & 7 \\
\hline & Total & 47,57 & 2,040 & Total & 370,38 & 180,986 & 21 \\
\hline & $100 \%$ & 45,16 & 1,739 & $100 \%$ & 250,00 & 122,820 & 14 \\
\hline \multirow[t]{3}{*}{ Hari 3} & $50 \%$ & 47,20 & 1,525 & $50 \%$ & 458,57 & 77,893 & 7 \\
\hline & Total & 45,84 & 1,906 & Total & 319,52 & 147,566 & 21 \\
\hline & $100 \%$ & 42,19 & 1,914 & $100 \%$ & 202,07 & 90,647 & 14 \\
\hline \multirow[t]{3}{*}{ Hari 4} & $50 \%$ & 45,95 & 2,426 & $50 \%$ & 394,29 & 54,347 & 7 \\
\hline & Total & 43,45 & 2,728 & Total & 266,14 & 121,852 & 21 \\
\hline & $100 \%$ & 40,03 & 1,787 & $100 \%$ & 178,50 & 83,493 & 14 \\
\hline \multirow[t]{2}{*}{ Hari 5} & $50 \%$ & 43,84 & 3,977 & $50 \%$ & 366,29 & 34,980 & 7 \\
\hline & Total & 41,30 & 3,194 & Total & 241,09 & 114,570 & 21 \\
\hline
\end{tabular}

Tabel 3. Analisis perbedaan dosis undur- undur (100\% vs $50 \%)$ terhadap glukosa darah dan hematokrit dengan uji Repeated Measure Anova

\begin{tabular}{lcccc}
\hline & \multicolumn{2}{c}{ Glukosa darah } & & Hematokrit \\
\cline { 2 - 5 } Hari ke- & $\mathrm{p}$-value & $95 \% \mathrm{Cl}$ & $\mathrm{p}$-value & $95 \% \mathrm{Cl}$ \\
\hline 1 & 0,73 & $0,069-0,079$ & 0,409 & $-1,64275-0,69846$ \\
2 & 0,025 & $0,022-0,028$ & 0,037 & $-3,73678--0,13036$ \\
3 & 0,001 & $0,000-0,001$ & 0,016 & $-3,66116--0,41741$ \\
4 & 0,000 & $0,000-0,001$ & 0,001 & $-5,78283--1,73431$ \\
5 & 0,000 & $0,000-0,001$ & 0,006 & $-6,40333--1,21095$ \\
\hline
\end{tabular}


Pengaruh Ekstrak Undur-undur (Myrmeleon sp) terhadap Glukosa Darah dan Hematokrit pada Tikus... Djap Hadi Susanto, Ronald Winardi Kartika, Pamela Hendra Heng, Adit Widodo Santoso, Maria VB Lopulalan, Angelina Wijaya
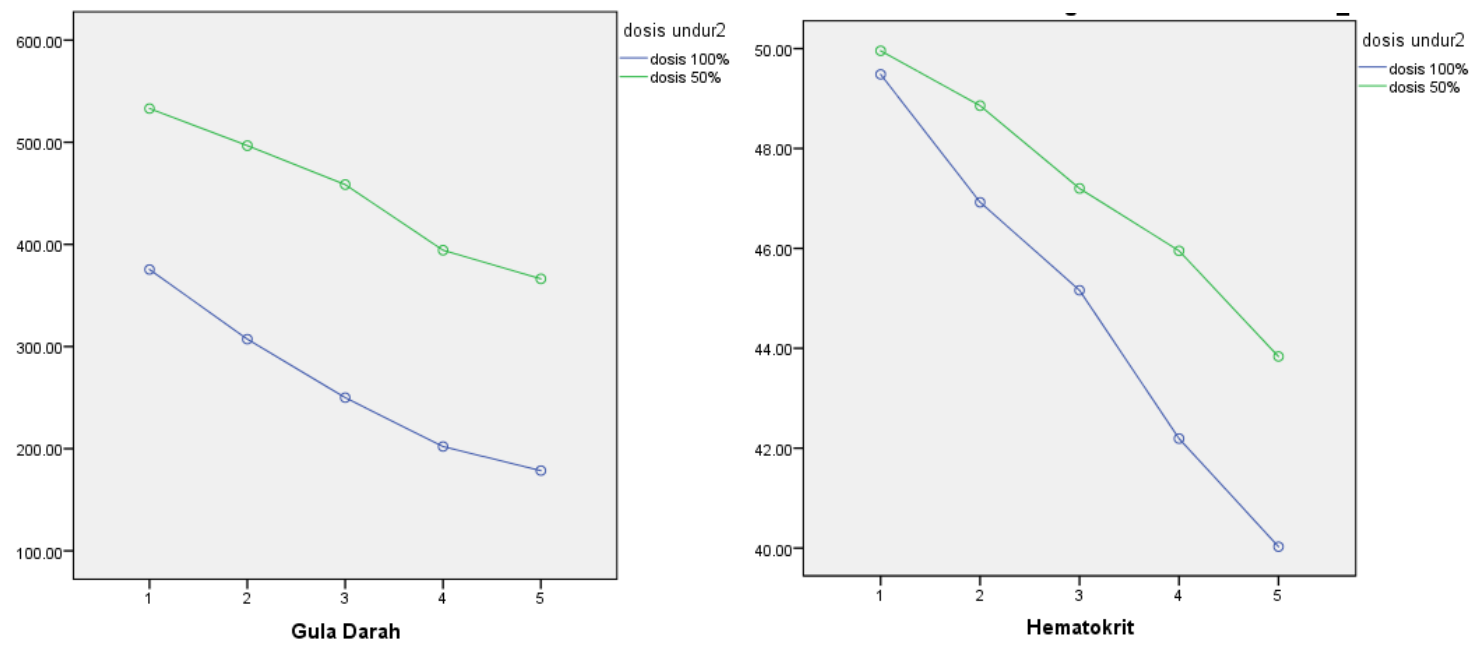

Gambar 1. Perbandingan penurunan Glukosa darah puasa dan Hematokrit hari ke 1 sampai hari ke 5

\section{PEMBAHASAN}

Efek terhadap penurunan gula darah sudah banyak dibuktikan oleh peneliti, hasil penelitian ini juga memberikan hasil serupa serta adanya variasi dosis undur-undur terhadap penurunan gula darah tikus diabetes. (Kurniasih et al, 2015; Rahma et al, 2016; Prihatin et al, 2019)

Terdapat perbedaan antara dosis $50 \%$ dan $100 \%$ terhadap perubahan glukosa darah mulai hari kedua sampai hari kelima. Semakin lama tampak semakin signifikan $(p=0,000)$. Demikian halnya dengan efek penurunan hematokrit, kadar glukosa darah juga menurun setelah pemberian pada hari kedua dan ketiga. Tidak diketahui juga berapa lama waktu yang dibutuhkan sehingga glukosa darah menjadi stabil. Hasil penelitian ini juga ditemukan oleh
Prihatin et al (2019), kestabilan glukosa darah dan hematokrit sangat penting dalam rangka mempertahankan tingkat hematokrit dan glukosa darah yang menetap. Jika tidak, akan cenderung menimbulkan hipoglikemia. Efek hipoglikemia juga didapatkan pada pemberian sulfonilurea. Mekanisme terjadinya penurunan hematokrit akibat ekstrak undur-undur masih perlu diteliti lebih lanjut.

Penurunan glukosa darah puasa pada hari pertama belum memperlihatkan penurunan yang signifikan $(p=0,098)$ dibandingkan dengan hari kedua, namun mulai terlihat adanya perbedaan penurunan yang signifikan antara hari pertama dengan hari ketiga $(p=0,005)$, hari keempat $(p=0,000)$ dan pada hari kelima $(p=0,000)$. Pemberian ekstrak undur-undur minimal 2 hari, baru memperlihatkan efek penurunan glukosa darah. Namun tidak 
ISSN 1978-2071 (Print); ISSN 2580-5967 (Online)

Jurnal Ilmiah Kedokteran Wijaya Kusuma 9(2) : 209-217, September 2020

diketahui berapa hari yang dibutuhkan untuk mempertahankan kestabilan glukosa darah, perlu dilakukan penelitian lanjut dengan jumlah hari pengamatan yang lebih lama. Besarnya dosis ekstrak undur-undur yang diberikan pada tikus sebesar $100 \mathrm{mg} / \mathrm{kgBB}$, agaknya sudah cukup memberikan efek yang nyata. Beberapa peneliti memberikan dosis yang lebih kecil pada tikus diabates. (Rahma et al, 2016) Masih diperlukan penelitian lebih lanjut mengenai dosis yang optimal dalam penurunan gula darah dan hematokrit.

Penurunan hematokrit mulai terlihat pada hari kedua dan seterusnya, variasi dosis ekstrak undur-undur juga memperlihatkan efek perbedaan kadar hematokrit, dan semakin bermakna sampai hari kelima. Demikian juga terhadap kadar glukosa darah. Ekstrak undurundur telah memperlihatkan perbedaan kadar glukosa darah puasa mulai hari kedua sampai hari kelima, seiring dengan perubahan kadar hematokrit. Hal ini menunjukkan bahwa ada perbedaan efek penurunan hematokrit dengan peningkatan dosis undur-undur. Hasil penelitian penurunan glukosa darah yang serupa juga ditemukan pada beberapa penelitian. (Afsar and Younus, 2004; Kurniasih, 2006) Sementara itu pengaruh undur-undur terhadap viskositas darah belum banyak diteliti.

\section{KESIMPULAN}

Hasil penelitian ini dapat disimpulkan bahwa ekstrak undur-undur mempunyai efek terhadap penurunan kadar hematokrit dan glukosa darah puasa pada tikus diabetes. Efek penurunan hematokrit dan glukosa darah puasa mulai terjadi setelah hari kedua. Terdapat perbedaan dosis pemberian ekstrak undurundur antara $50 \%$ dan 100\%. Semakin tinggi dosis yang diberikan akan memberikan efek penurunan gula darah yang lebih nyata dan cepat Ekstrak undur-undur (Myrmeleon sp.) dapat digunakan untuk mengendalikan glukosa darah dan sekaligus menurunkan konsentrasi hematokrit yang pada umumnya menyertai penderita diabetes mellitus. Dengan adanya perbedaan dosis, maka disarankan agar masyarakat yang mengkonsumsi undur-undur sebagai bahan alamiah penurun gula darah, bersikap lebih hati-hati dengan efek hipoglikemik penderita diabetes mellitus. Ekstrak undur-undur dapat dipergunakan sebagai satu satu alternatif pengobatan tradisional di daerah yang akses jangkauan pelayanan kesehatan modernnya masih terbatas. Efek penurunan hematokrit dapat dilanjutkan dengan penelitian yang lebih lanjut dari segi patofisiologisnya. 
Pengaruh Ekstrak Undur-undur (Myrmeleon sp) terhadap Glukosa Darah dan Hematokrit pada Tikus...

Djap Hadi Susanto, Ronald Winardi Kartika, Pamela Hendra Heng, Adit Widodo Santoso, Maria VB Lopulalan, Angelina Wijaya

\section{DAFTAR PUSTAKA}

Afsar HA, and Younus M, 2004. Patient Referral at the Grass-Roots Level in Pakistan. Nature and Science. 2(4): 18-27.

Badan Litbangkes Depkes RI, 2010. Riset kesehatan dasar 2010.

Badan Litbangkes Depkes RI, 2013. RISET KESEHATAN DASAR.

Dewi MR, 2014. Undur-undur darat (Myrmeleon sp.) sebagai Obat Alternatif Diabetes Melitus. Jurnal Ilmu Peternakan.

Djap HS, Sutrisna B, Soewondo P, Djuwita R, Timotius $\mathrm{KH}$, et al, 2018. Waist to Height Ratio (0.5) as a Predictor for Prediabetes and Type 2 Diabetes in Indonesia. IOP Conference Series: Materials Science and Engineering. IOP Publishing, 434: 12311.

Huber CA, Schwenkglenks M, Rapold $R$ and Reich O, 2014. Epidemiology and Costs of Diabetes Mellitus in Switzerland: An Analysis of Health Care Claims Data, 2006 and 2011. BMC Endocrine Disorders. 14(1): 1-9.

Irace C, Scarinci F, Scoria V, Bruzzichessi D, Fiorentino $\mathrm{R}$, et al, 2011. Association among Low Whole Blood Viscosity, Haematocrit, Haemoglobin and Diabetic Retinopathy in Subjects with Type 2 Diabetes. British Journal of Ophthalmology. 95(1): 94-98.
Kurniasih T, Isma'il M, Susilowati F, dan Lestari SP, 2015. Kajian potensi undur-undur darat (Myrmelon sp.) sebagai antidiabetes. PKMP-2-216-1

Kurniasih $T$, Isma'il $M$, Susilowati $F$, Lestari SP, 2006. Kajian potensi undur-undur darat (Myrmeleon sp) sebagai antidiabetes. thesis. Fakultas Biologi, Universitas Gadjah Mada, Yogyakarta.

Muadifah A, Sulistyarti H, and Prasetyawan S, 2017. Liquid Chromatography for Analysis of Metformin in Myrmeleon sp. The Journal of Pure and Applied Chemistry Research. 6(3): 196-206.

Mujahid ZM, 2013. A Combination of Bitter Gourd Ethanolic Extract with Ant Lion Larvae Aqueous Extract for a Blood Glucose-Lowering Agent. IFRJ. 20(2): 851-855.

Narulita E, Iqbal M, Surakhman G, 2019. A Novel Antibacterial Agent of Myrmeleon formicarius Extract for Diabetic Ulcer Infection. Indonesian Journal of Biotechnology and Biodiversity. 3(2): 48-54.

PB Perkeni, 2015. Pengelolaan dan pencegahan diabetes melitus tipe 2 di indonesia 2015.

Prihatin J, Narulita E, Mufidah L, Kurniawan A, Wulandari D, et al, 2019. 
ISSN 1978-2071 (Print); ISSN 2580-5967 (Online) Jurnal Ilmiah Kedokteran Wijaya Kusuma 9(2) : 209-217, September 2020

Antihyperglycaemic And Tissue-Repair Effects of Myrmeleon Formicarius Extract in Streptozotocin-Induced Diabetic Mice. Journal of Taibah University Medical Sciences. 14(2): 149-155.

Rahma HH, Sundhani E, and Nurulita NA, 2016. Antidiabetic Activity of Powder and Ethanolic Extract of Antlion (Myrmeleon Sp.) on Wistar Strain White Male Rats with Glucose Preload. Proceeding ICMHS. 2016: 14-16.

Soegondo S, 2008. Apakah penyakit dabetes melitus itu?', in Hidup secara mandiri dengan diabetes melitus kencing manis sakit gula. Balai Penerbit FKUI: 1-11.

Sudharsanan N, Ali MK, Mehta NK, and Narayan KMV, 2015. Population Aging, Macroeconomic Changes, and Global Diabetes Prevalence, 1990-2008, Population Health Metrics. 13(1): 1-8.

Sutanto F, 2008. Daya Hambat Ekstrak Metanol Undur-Undur terhadap Aktivitas Enzim A-Glukosidase sebagai Antidiabetes. Skripsi. Institut Pertanian Bogor.
Tamariz LJ, Young JH, Pankow JS, Yeh HC, Schmidt MI, Astor B, and Brancati FL, 2008. Blood Viscosity and Hematocrit as Risk Factors for Type 2 Diabetes Mellitus: The Atherosclerosis Risk in Communities (ARIC) Study. American Journal of Epidemiology. 168(10): 1153-1160.

Tulloch-Reid MK, Hanson RL, Saremi A, Looker HC, Williams DE, et al, 2004. Hematocrit and the Incidence of Type 2 Diabetes in the Pima Indians. Diabetes Care. 27(9): 2245-2246.

Wang W, Lee ET, Howard BV, Fabsitz RR, Devereux RB, et al, 2011. Fasting Plasma Glucose and Hemoglobin A1C in Identifying and Predicting Diabetes: The Strong Heart Study. Diabetes Care. 34(2): 363-368.

Whiting DR, Guariguata L, Weil C, and Shaw J, 2011. IDF Diabetes Atlas: Global Estimates of the Prevalence of Diabetes for 2011 and 2030. Diabetes Research and Clinical Practice. 94(3): 311-321. 